\title{
Review: Exogenous butyrate: implications for the functional development of ruminal epithelium and calf performance
}

\author{
B. Niwińska ${ }^{1 \dagger}$, E. Hanczakowska ${ }^{1}$, M. B. Arciszewski ${ }^{2}$ and R. Klebaniuk ${ }^{3}$ \\ ${ }^{1}$ Department of Animal Nutrition and Feed Science, National Research Institute of Animal Production, Krakowska 1, 32-033 Balice, Poland; ${ }^{2}$ Department of \\ Animal Anatomy and Histology, University of Life Sciences, Akademicka 12, 20-033 Lublin, Poland; ${ }^{3}$ Department of Animal Nutrition and Bromatology, University of \\ Life Sciences, Akademicka 13, 20-950 Lublin, Poland
}

(Received 24 June 2016; Accepted 16 December 2016; First published online 14 February 2017)

The importance of the use of exogenous butyrate in calves' diets is due to its role as a factor stimulating the functional development of ruminal epithelium and improving calf performance during the transition from preruminant to ruminant status. Our review will first present results related to effects of the administration of butyrate in calves' diets on the development of ruminal epithelium toward a more effective absorption and metabolism of fermentation products from the rumen. The introduction of sodium butyrate at a level of about $0.3 \%$ of diet dry matter is accompanied by an increase to $35 \%$ in butyrate concentration in the rumen of 33-day-old calves. Mutual reliance between an enhanced ruminal concentration of butyrate and the activities of transcription factors, genes and proteins involved in cell proliferation, ketogenesis and the maintenance of cell $\mathrm{pH}$ homeostasis in the ruminal epithelial cells has been clearly confirmed in many experiments. Second, the review presents results related to the effects of the introduction of butyrate salts in the diet on calf performance. Of 11 studies a positive effect was found in six; five of these were obtained from the calves that started receiving butyrate supplement at a level of about $0.3 \%$ diet dry matter from the age of 3 to 5 days. Results indicate that when a supplement is given to calves soon after birth the functional development of ruminal epithelium in cooperation with the endocrine and digestion systems is transferred into improving the efficiency of rearing. There have been no studies on the effects of greater amounts of butyrate salts in milk replacer; butyrate constitutes about 1.2\% of the whole cow's milk dry matter. In older calves, when butyrate administration is provided as a component of a starter concentrate at the increasing inclusion rate from $0.3 \%$ to $3.0 \%$, the practical effect in calf performance relates to the risk of depression of rumen $\mathrm{pH}$ below 5.5 and accompanying disruption of the organization of the ruminal epithelial tissue. The higher risk is noted in calves received starter with substantial content of a rapidly degradable starch. At present, the insufficient number of positive results confirming the beneficial effect of butyrate supplements in terms of an improvement in performance does not allow their recommendation for use in the practical feeding of calves.

Keywords: calves, butyrate, rumen, epithelium, development

\section{Implications}

The functional development of the ruminal epithelium which covers the luminal surface of the rumen is crucial for proper solid feed utilization and body functions during the transition from a preruminant to a ruminant state in cattle. This review presents a discussion of recent investigations on the role of exogenous butyrate in the morphological and metabolic maturation processes in ruminal epithelial cells. In addition, the effects of the introduction of butyric acid salts into a diet in terms of improving calf performance are discussed, and some areas for future investigation are identified.

\footnotetext{
${ }^{\dagger}$ E-mail: barbara.niwinska@izoo.krakow.p
}

\section{Introduction}

The luminal surface of the rumen is covered by a stratified epithelium which, during the transition from preruminant to ruminant status and due to dietary changes from liquid to solid feeds, undergoes a functional rebuild. The ruminal epithelium in preruminants undergoes maturation processes associated with the enlargement of the surface area for nutrient absorption and the development of ruminal epithelial cell capabilities for absorption and metabolism of shortchain fatty acids (SCFA) generated by the digestion of solid feed nutrients through the action of anaerobic microorganisms in the rumen (Bergman, 1990; Baldwin and Jesse, 1992). The functional development of rumen epithelium is 
stimulated by butyric acid (Sander et al., 1959). An increase in butyric acid concentration in the rumen causes the enlargement of the ruminal epithelium absorptive surface area (Mentschel et al., 2001; Naeem et al., 2012; Malhi et al., 2013) and accelerates the oxidation of SCFA in the ketogenesis pathway (Connor et al., 2013; Yan et al., 2014). Recent reports support the hypothesis that an increase in butyric acid concentration is the basic factor influencing ruminal epithelium maturity.

With increasing prices of milk replacer ingredients, there is economic pressure to reduce the preweaning transition period for calves from their neonatal reliance on nutrients supplied from liquid feed to nutrients supplied from less expensive solid feed (Baldwin et al., 2004). For efficient solid feed utilization, the proper and rapid functional development of rumen epithelium is needed. The acceleration of epithelium development can be achieved by the addition of butyric acid salts into a calf's diet (Gorka et al., 2009; Malhi et al., 2013); however, the practical effects in terms of improvements in calf performance have been both positive (Górka et al., 2011a and 2011b; Nazari et al., 2012) and negative (Araujo et al., 2015; Wanat et al., 2015), and some results do not confirm these relationships (Kato et al., 2011). Therefore, it is equivocal as to whether exogenous butyrate could play a role as a factor stimulating the development of ruminal epithelium and that the consequences of these activities are improvements in calf performance.

This review presents results from studies on the effects of exogenous butyrate on the functional development of ruminal epithelium. In addition, we determine whether these effects are transferred into improving calf performance.

\section{Butyric acid in calf rumen}

Butyric acid (systematic name butanoic acid, structural formula $\mathrm{CH}_{3} \mathrm{CH}_{2} \mathrm{CH}_{2}-\mathrm{COOH}$ ), a weak acid with acid dissociation constant $\mathrm{p} K_{\mathrm{a}}=4.82$, is a natural substance present in the sites of microbial fermentation in the gastrointestinal tract, and as a natural component of colostrum, milk, sweat and feces of most mammals, as well as a component of the cellular metabolism in all tissues. In the gastrointestinal tract, $90 \%$ to $99 \%$ of butyric acid is present as an anion, and for the purpose of the review the term 'butyrate' is used interchangeably for the acid and anion forms. Butyrate is one of the SCFA, the saturated aliphatic organic acids that consist of one to six carbons. Short-chain fatty acid concentrations in the rumen fluid of 8-week-old veal calves vary from 36 to $120 \mathrm{mM} / \mathrm{l} ;$ and the acetate, propionate and butyrate $(92 \%$ to $95 \%)$ are present at a molar ratio of $63: 27: 10$ to $53: 30: 17$ (Súarez et al., 2007). Among the most abundant SCFA, butyrate is recognized as the major stimulator of the functional development of ruminal epithelium, because it is the most extensively absorbed and, to a large extent, metabolized SCFA in the epithelium and its energy value is higher than that of propionate and acetate (Bergman, 1990; Rémond et al., 1995; Gäbel and Sehested, 1997). More recently, results have indicated that butyrate regulates the chromatin-remodeling activity of histone deacetylases and this process results in a modulation of gene expression in epithelial cell proliferation (Donohoe et al., 2012). The role of butyrate in the development of ruminal epithelial cells relates to its importance as a substrate of cell metabolism and as a regulator of gene activities. During the period from birth to weaning, the concentration of butyrate in rumen increases from $0.002 \mathrm{mM} / \mathrm{l}$ to a concentration between 5.1 and $17.3 \mathrm{mM} / \mathrm{l}$ (Lesmeister and Heinrichs, 2004; Súarez et al., 2007; Laarman et al., 2012). The elevation of the intraruminal concentration of butyrate within the normal physiological range accelerates the maturation processes in the ruminal epithelial cells in calves (Laarman et al., 2012; Connor et al., 2014). This concentration is modulated by varying the quality and quantity of feeds. A higher concentration of butyrate is found in the rumen of calves fed with milk in comparison with those receiving milk replacer without milk fat (Niwińska and Strzetelski, 2004). An increase in the concentration of butyrate has been noted in calf rumen as the consumption of solid feed increases and in those calves receiving starter concentrate with higher content of more rapidly fermentable carbohydrates (e.g. sugars and starches) in (Khan et al., 2008; Laarman et al., 2012; Khan et al., 2016). The rapidly fermentable carbohydrates present during rumen fermentation are an essential source of butyric acid. However, the provision of a butyrogenic starter diet could cause a low ruminal $\mathrm{pH}$ and may negatively affect the development of the rumen (Khan et al., 2008; Liu et al., 2013). Given this risk, the introduction of butyrate salts into the diet seems to be the simplest way to enhance ruminal butyrate concentration. Researchers have demonstrated a $25 \%$ to $35 \%$ increase in butyrate concentration in the rumen of 33-day-old calves as an effect of the introduction of butyrate salts in the form of sodium or calcium butyrate into diet at the level of $0.3 \%$ of ration dry matter (DM) (Gorka et al., 2009; Nazari et al., 2012). The results of studies have indicated that exogenous butyrate introduced in the form of butyrate salts in the diet contributes to an increase in the butyrate concentration in the rumen of calves.

\section{Exogenous butyrate in the functional development of the ruminal epithelium}

The ruminal epithelium overlays rumen papillae, the increase of which in terms of number and size results in an increased surface area and potential for nutrient absorption (Gäbel et al., 2002). The elevation of intraruminal concentrations of butyrate through its administration modulates the surface epithelium (Sakata and Tamata, 1978). The latest results regarding the effects of exogenous butyrate on the morphology of rumen papillae in preruminants are presented in Table 1. A substantial increase in papillary length has been observed as a consequence of the introduction of sodium butyrate at a level near $0.3 \%$ in ration DM, and there has been an accompanying increase in butyrate concentration in the ruminal content in calves (Mentschel et al., 2001; Gorka et al., 2009; Kato et al., 2011; Górka et al., 2011a and 2011b) and in lambs (Cavini et al., 2015) compared with animals receiving diets without butyrate supplementation. 
Niwińska, Hanczakowska, Arciszewski and Klebaniuk

Table 1 The effects of exogenous butyrate on the growth of rumen papillae in preruminants

\begin{tabular}{|c|c|c|c|c|c|c|}
\hline \multicolumn{4}{|c|}{ Effect $^{1}$} & \multirow[b]{3}{*}{ Animals $^{2}$} & \multirow[b]{3}{*}{ Na-butyrate supplementation } & \multirow[b]{3}{*}{ References } \\
\hline \multicolumn{3}{|c|}{ Rumen papillae } & \multirow[b]{2}{*}{ Surface area } & & & \\
\hline Length & Width & Density & & & & \\
\hline$+* *$ & & & & Calves & $3 \mathrm{~g} / \mathrm{kg} \mathrm{BW}$ & Mentschel et al. (2001) \\
\hline$+* *$ & $+* *$ & & & & $0.3 \%$ (as fed) & Gorka et al. (2009) \\
\hline$+{ }^{*}$ & $+^{*}$ & & & & $0.3 \% \mathrm{DM}$ & Górka et al. (2011b) \\
\hline$+{ }^{\#}$ & $+^{*}$ & & & & $0.3 \% \mathrm{DM}$ & Górka et al. (2011a) \\
\hline$+\#$ & & & & & 3 to $7 \mathrm{~g} /$ day & Kato et al. (2011) \\
\hline$++^{\#}$ & Ns & Ns & & Lambs & $0.36 \% \mathrm{DM}$ & Cavini et al. (2015) \\
\hline$+* *$ & $+^{*}$ & $+^{\#}$ & $+* *$ & Goats & $0.3 \mathrm{~g} / \mathrm{kg} \mathrm{BW}$ & Malhi et al., 2013 \\
\hline
\end{tabular}

Table 2 The possible mechanisms of regulation of epithelial cell proliferation by an increase in the concentration of butyrate in the rumen

\begin{tabular}{|c|c|c|c|c|c|c|}
\hline \multirow[b]{2}{*}{ Items } & & \multirow[b]{2}{*}{ Effect $^{1}$} & \multicolumn{2}{|c|}{ Butyrate } & \multirow[b]{2}{*}{ Animals $^{3}$} & \multirow[b]{2}{*}{ References } \\
\hline & & & Source & Concentration $^{2}$ & & \\
\hline $\begin{array}{l}\text { Mitotic - apoptotic } \\
\text { equilibrium }\end{array}$ & Mitotic index ${ }^{4}$ & $+^{*}$ & Diet supplement & $\begin{array}{l}\text { Sevenfold } \\
\text { increase }\end{array}$ & Calves & Mentschel et al. (2001) \\
\hline Activities of nuclear factors & $\begin{array}{l}\text { Peroxisome proliferator- } \\
\text { activated receptor- } \alpha \\
\text { Forkhead box protein } 01 \\
\text { Transforming growth factor- } \beta 1\end{array}$ & $\begin{array}{c}+^{\#} \\
\mathrm{IPA}^{6} \\
+^{*} \\
\mathrm{IPA}+\end{array}$ & $\begin{array}{l}\text { Ruminal } \\
\text { fermentation }\end{array}$ & & & $\begin{array}{l}\text { Naeem et al. (2012) } \\
\text { Connor et al. (2013) } \\
\text { Naeem et al. (2012) } \\
\text { Connor et al. (2014) }\end{array}$ \\
\hline Regulation of the cell cycle & $\begin{array}{l}\text { proportion of cells in G0/G1 to S state } \\
\text { D-type cyclin, isoform } 1\end{array}$ & $\begin{array}{l}-^{\#} \\
+^{*}\end{array}$ & Ruminal infusion & $+{ }^{*}$ & Goats & Malhi et al. (2013) \\
\hline $\begin{array}{l}\text { Regulation of the energy } \\
\text { delivery }\end{array}$ & Ruminal vacuolar $\mathrm{H}^{+}$-ATPase & $+^{*}$ & $\begin{array}{l}\text { Ruminal } \\
\text { fermentation }\end{array}$ & $+* *$ & Lambs & Kuzinski et al. (2012) \\
\hline
\end{tabular}

ATPase $=$ adenosine triphosphatase.

${ }^{1}$ The level of statistical significance was declared (at $P$-value): ${ }^{*} P \leqslant 0.1 ;{ }^{*} P \leqslant 0.05 ;{ }^{* *} P \leqslant 0.01 ;(+)$ increase; (-) decrease.

${ }^{2}$ The increase in comparison with control groups.

${ }^{3}$ The age of calves was from 35 to 70 days, of goats 150 days and of lambs 7 months.

${ }^{4}$ The proportion of cells in a tissue undergoing mitosis.

${ }^{5}$ The source of butyrate was the rumen fermentation of starter concentrate.

${ }^{6}$ The results estimated by Ingenuity Pathway Analysis (Qiagen, Redwood City, CA, USA) on the base of statistics and algorithms of relationships among activities of nuclear factors in proliferation of epithelial cell and an increase in the concentration of butyrate in the rumen.

${ }^{7}$ The proportion of the fraction of cell in diploid resting state (G0/G1) to the fraction of cell in synthesis state double the amount of nuclear material (S) during the sequential phases of the cell cycle.

Similarly, significant and positive effects on papillary size, density and surface area (approximately by $82 \%$ ) have been observed in goats after intraruminal butyrate infusion, when supporting a concentration within the normal physiological range (Malhi et al., 2013). These results demonstrate that the administration of exogenous butyrate into the ration is accompanied by an increase in the number of papillae, together with their marked growth in terms of length and width. The mechanism responsible for the development of papillae resulting from elevated butyrate concentrations is explained in different ways (Table 2). Exogenous butyrate has been assigned the roles of a stimulator of mitotic rate, and an inhibitor of apoptosis (Mentschel et al., 2001) and a modulator of cell cycle progression (Malhi et al., 2013) in ruminal epithelial cells. The cell cycle is promoted by the faster transition from the diploid DNA resting state (G0/G1) to the synthesis state (S), double the amount of nuclear material of single epithelial cells (Shen et al., 2005) and the activities of cyclin D-type, isoform1 (CCND1) and cyclin-dependent kinase type 4 (CDK4), the key regulators responsible for transition from G1 to $S$ phase (King and Cidlowski, 1998). Exogenous butyrate decreases the proportion of the cellular fraction in G0/G1 phase to the cellular fraction in the $S$ phase and increases the messenger RNA (mRNA) expression of CCND1 and CDK4 in the ruminal epithelial cells (Malhi et al., 2013). In addition to regulation of the cell cycle, the relationship between the energy requirements, the intracellular $\mathrm{pH}(\mathrm{pHi})$ and the proliferation process of the ruminal epithelial cells is of particular importance. A higher activity of vacuolar-type $\mathrm{H}^{+}$-adenosine 
triphosphatase ( $\mathrm{vH}^{+}$-ATPase), a sensor of substrate and energy availability participating in $\mathrm{H}^{+}$translocation across limiting membranes and of the peroxisome proliferatoractivated receptor isoform- $\alpha$ (PPAR $\alpha$ ) involved in energy homeostasis and in cell cycle, has been estimated in proliferated epithelial cells in rumen with higher butyrate concentrations (Kuzinski et al., 2012; Naeem et al., 2012; Connor et al., 2013). The process of cell division is connected with $\mathrm{pHi}$ changes which are induced metabolically (Madshus, 1988). This dependence is confirmed by the higher activities of transcription factors related to the proliferation pathways, such as the forkhead box protein 01 (FOXO1) and the transforming growth factor- $\beta 1$, as well as those related to energy production, such as estrogen-related receptor $\alpha$ in cooperation with PPAR $\alpha$ observed as an effect of enhancing nutrition levels in calves (Connor et al., 2014). These results indicate that elevated butyrate concentration accelerates the proliferation of the ruminal epithelial cells by stimulation of the cell cycle, activities of proteins regulating cell division, pHi changes and the availability of energy to the dividing cells.
In addition to morphological development, the hallmark of metabolic development of ruminal epithelium tissue is ketogenesis, which is based on the ability to convert SCFA to the ketone bodies used as sources of oxidative fuels in the various tissues (Hegardt, 1999; Allen, 2014). In physiologically mature rumen epithelium between $75 \%$ and $90 \%$ of absorbed butyrate is metabolized and $\sim 83 \%$ of metabolized butyrate is converted into $\beta$-hydroxybutyrate and acetoacetate (Rémond et al., 1995; Gäbel and Sehested, 1997). The increase in butyrate concentration in calf rumen stimulates changes in the activities of genes and proteins involved in the ketogenesis pathway. The latest results concerning this area are summarized in Table 3. Acetyl-CoA acetyl transferase (ACAT) and 3-hydroxy-3-methylglutaryl CoA synthase (HMG-CoA synthase) play rate limiting roles in the ketogenesis process (Lane et al., 2002). Increases in the mRNA abundance of ACAT isoform 1 (ACAT1), HMG-CoA synthase soluble isoform 1 (HMGCS1) and HMG-CoA synthase isoform 2 (HMGCS2) in response to a threefold increase in butyrate concentration in rumen liquid (Laarman et al., 2012; Connor et al., 2013) and in HMGCS1 in response to enhanced levels

Table 3 The effects of elevated intraruminal concentration of butyrate on the activity of proteins involved in the metabolism of rumen epithelial cells

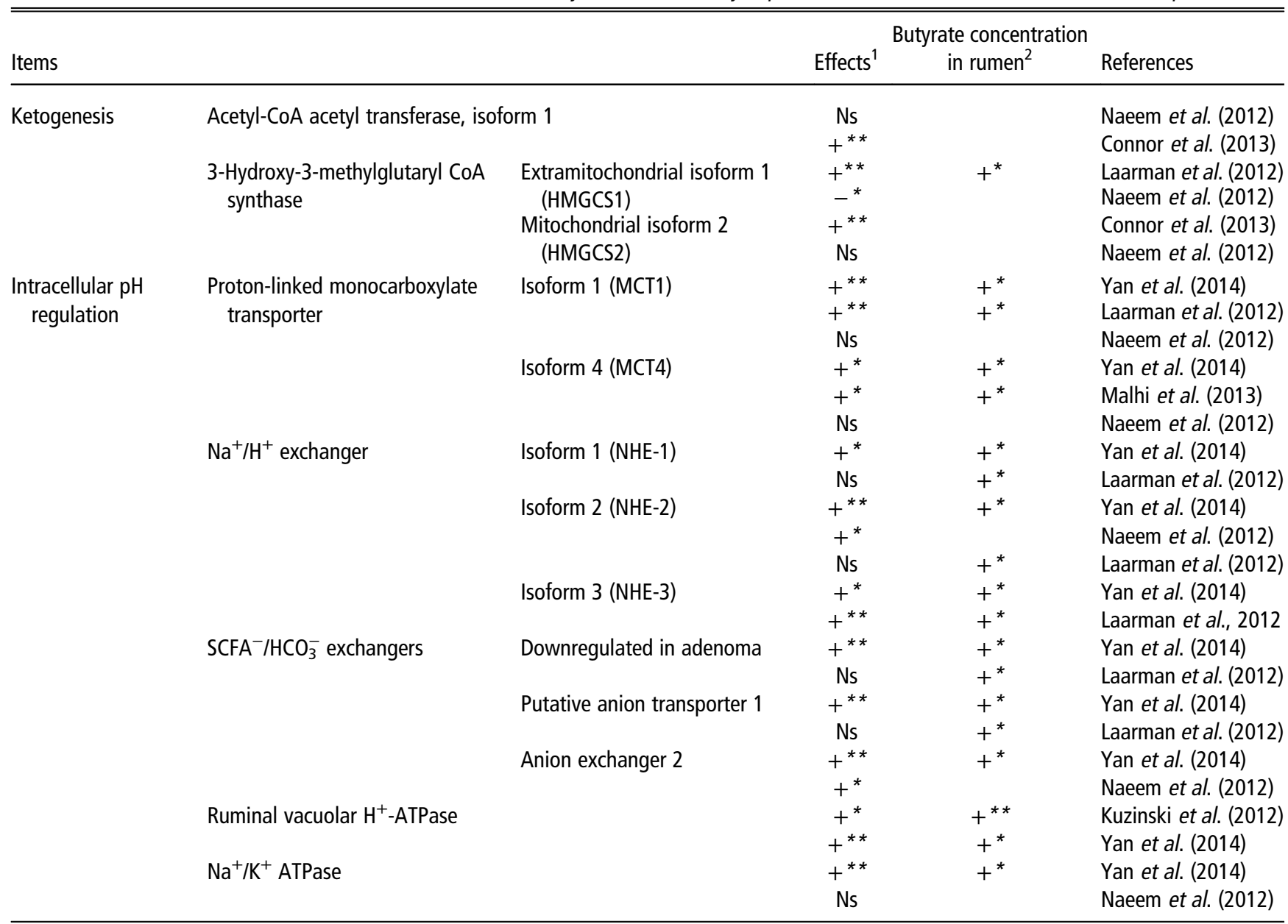

ATPase $=$ adenosine triphosphatase.

${ }^{1}$ The level of statistical significance in differences was declared (at $P$-value): Ns $P>0.1 ;{ }^{*} P \leqslant 0.05 ;{ }^{*} P \leqslant 0.01 ;(+)$ increase; $(-)$ decrease.

${ }^{2}$ The increase in comparison with control groups. 
of nutrition and increasing butyrate concentrations (Naeem et al., 2012) have been observed in the ruminal epithelial cells of calves. The expression of HMGCS2 in the rumen has been found to be significantly higher postweaning than preweaning, thus supporting the existence of a positive relationship between ketogenesis and increasing rumen fermentation induced by intake of solid feed (Kato et al., 2016). In addition, on the basis of results of over-time and within diet analysis of differentially expressed genes (using the Permutation Analysis of Differential Expression), it has been proposed that transcription factor PPAR $\alpha$ is a regulator of ACAT1 and HMGCS2 gene activities (Connor et al., 2013). PPAR $\alpha$ is identified as a regulator of ketogenesis development in epithelial cells during the transition from prerumination to rumination state, and its activities are regulated by butyrate availability. In summary, these observations indicate a desirable relationship between an elevated concentration of butyrate in the rumen and the acceleration of ketone formation in the rumen epithelial cells.

The uptake and the metabolism of butyrate are rapid; the constant rate related to the butyrate flux from ruminal fluid to epithelial cells has been estimated at $0.97 / \mathrm{h}$, and the absorption of butyrate by epithelial cells results in an elevation in pHi of about $0.45 \mathrm{pH}$ units (Etschmann et al., 2006; Storm et al., 2012). After entry into the cells, the protonated form of butyrate readily dissociates, thereby delivering $\mathrm{H}^{+}$to the cell interior, and the intraepithelial butyrate metabolism gives rise to $\mathrm{CO}_{2}$, the hydration of which supplies not only $\mathrm{H}^{+}$ but also carbonic acid (Schweigel et al., 2000). The butyrateinduced acid load in the ruminal epithelial cells stimulates the activities of proteins involved in the pHi recovery to the values of cell homeostasis. These $\mathrm{pH}$-homeostatic mechanisms include membrane-bound transporters belonging to the solute-carrier family, isoforms of (monocarboxylate transporter (MCT)), sodium-proton exchangers (NHEs) and also P-type cation transport adenosine triphosphatases (Graham et al., 2007; Kuzinski et al., 2012). It has been recognized that an increasing ruminal concentration of butyrate stimulates the activities of proton-linked monocarboxylate transporter isoform 1 (MCT1) and/or isoform 4 (MCT4) in transporting carboxylic acids in the ruminal epithelial cells in calves (Laarman et al., 2012), goats (Yan et al., 2014) and lambs (Malhi et al., 2013). The positive relationship between the activities of MCT1 and MCT4 and the intracellular concentrations of butyrate and ketone bodies indicates that these proteins mediate transruminal fluxes of butyrate and butyrate metabolites in the ruminal epithelium (Dengler et al., 2015). An increasing ruminal concentration of butyrate activates NHE isoforms 1, 2 and 3 in the ruminal epithelial cells in calves (Laarman et al., 2012; Naeem et al., 2012) and in goats (Yan et al., 2014). NHE-3 is very sensitive to changes in SCFA concentration. The full activity of NHEs has been recognized as a key transport element required for $\mathrm{Na}^{+} / \mathrm{K}^{+}$-ATPase and $\mathrm{vH}^{+}$-ATPase functions in the regulation of pHi homeostasis (Albrecht et al., 2008). Activities of these both enzymes in the rumen epithelium are positively affected by an increasing ruminal concentration of butyrate in goats and lambs (Kuzinski et al., 2012; Yan et al., 2014). Butyrate exerts a positive effect on the pHi-homeostatic mechanisms allowing butyrate to pass from the rumen in the ruminal epithelial cells and butyrate metabolites into the capillary bed. The above literature collectively demonstrates that the provision of exogenous butyrate into the diet elevates butyrate concentrations in the calf rumen and positively affects the morphological and metabolic functions of the ruminal epithelial cells. These results suggested that metabolic development of the ruminal epithelial tissue driven by exogenous butyrate may positively affects calf performance.

\section{Exogenous butyrate in calf rearing}

The results of experiments investigating the effects of exogenous butyrate on calf performance is based on the daily weight gain, feed intake and feed conversion for BW gain (Table 4). In all the presented studies, the effects of butyrate supplementation on performance have been estimated in relation to those characterized in calves receiving unsupplemented diet. In these studies, sodium or calcium butyrate provided in milk replacer and/or starter concentrate at a rate of about $0.3 \%$ of the diet DM were used as a sources of exogenous butyrate. Positive effects on the daily weight gain, at the probability at least 0.1 , have been reported in six studies. Five of them were obtained from the calves that started receiving butyrate supplement from 3 to 5 days of age as a component of milk replacer and/or starter concentrate et the level (Gorka et al., 2009; Górka et al., 2011a and 2011b; Nazari et al., 2012; Serbester et al., 2014). The results indicate that the improvement of performance is found during the $1^{\text {st }}$ week of the preweaning period in calves that started receiving butyrate supplement from the 1st day of life. The improvement of performance was not observed when administration of butyrate as a component of milk replacer is started from day 12 of life (Guilloteau et al., 2010; Araujo et al., 2015). The results indicated that the practical effects in improvement of performance depend on the age at which the calf started to receive the supplementation. The ruminal concentration of butyrate in neonate calves is low, $\sim 0.002 \mathrm{mM} / \mathrm{l}$, similar to the plasma concentrations (Lesmeister and Heinrichs, 2004). The response to exogenous butyrate administration in calves aged 26 to 33 days is clearly noticeable in the elevated ruminal concentration of butyrate (Gorka et al., 2009; Nazari et al., 2012) and in the increase in the rumen area (Gorka et al., 2009; Górka et al., 2011a and 2011b). In accordance with the ontogenic development, the secretion of digestive enzymes soon after birth progressively increases and the exogenous butyrate additionally stimulates both the secretion of enzymes and their activities in the digestion of DM, protein and fat (Guilloteau et al., 2009; Guilloteau et al., 2010). Recent studies also point to the impact of butyrate on the activity of the endocrine system. The increase in the concentrations of gastrin, secretin, cholecystokinin, glucagon-like peptide 2 , and IGF-1 in the blood and the increase in IGF-receptor 1 in the ruminal epithelial cells have been observed as a result of 
Table 4 The effects of exogenous butyrate on calf performance

\begin{tabular}{|c|c|c|c|c|c|c|c|}
\hline \multirow[b]{2}{*}{$\begin{array}{l}\text { Rearing } \\
\text { periods }\end{array}$} & \multicolumn{3}{|c|}{ Supplements } & \multicolumn{3}{|c|}{ Effects $^{1}$} & \multirow[b]{2}{*}{ References } \\
\hline & Included in & At level & $\begin{array}{l}\text { Period } \\
\text { (days of age) }\end{array}$ & $\begin{array}{l}\text { Daily weight } \\
\text { gain }\end{array}$ & $\begin{array}{l}\text { Feed } \\
\text { intake }\end{array}$ & $\begin{array}{c}\text { Feed } \\
\text { conversion } 2\end{array}$ & \\
\hline \multirow[t]{12}{*}{ Preweaning $^{3}$} & Milk replacer & $3 \mathrm{~g} /$ day & 3 to 48 & $+^{*}$ & $+^{*}$ & $+^{*}$ & Nazari et al. (2012) \\
\hline & & 3 to $7 \mathrm{~g} /$ day & 4 to 42 & Ns & Ns & Ns & Kato et al. (2011) \\
\hline & & $0.3 \%$ (as fed) & 5 to 26 & $++^{\# 4}$ & Ns & Ns & Górka et al. (2011b) \\
\hline & & $0.3 \%$ (as fed) & 5 to 26 & $+^{\#}$ & Ns & & Górka et al. (2011a) \\
\hline & & $0.3 \% \mathrm{DM}$ & 12 to 45 & Ns & & & Guilloteau et al. (2010) \\
\hline & & $0.3 \% \mathrm{DM}$ & 12 to 47 & Ns & Ns & $-^{*}$ & Araujo et al. (2015) \\
\hline & $\begin{array}{l}\text { Milk replacer and } \\
\text { starter concentrate }\end{array}$ & $0.3 \%$ (as fed) & 5 to 26 & $+^{\#}$ & Ns & & Gorka et al. (2009) \\
\hline & Starter concentrate & $0.3 \%$ (as fed) & 5 to 26 & Ns & $t^{\#}$ & & Górka et al. (2011a) \\
\hline & & $0.3 \%$ (as fed) & 4 to 35 & $+{ }^{*}$ & Ns & $+^{*}$ & Serbester et al. (2014) \\
\hline & & $0.15 \% ; 5.0 \%$ (as fed) & & Ns & Ns & Ns & Ślusarczyk et al. (2010) \\
\hline & & $0.3 \% ; 1 \% ; 3 \% \mathrm{DM}$ & 12 to 57 & $+^{*}$ & $t^{\#}$ & & Wanat et al. (2015) \\
\hline & & $0.3 \% ; 0.6 \% ; 0.9 \%$ (as fed) & 13 to 62 & $-{ }^{*}$ & $-{ }^{* *}$ & Ns & \\
\hline \multirow[t]{2}{*}{ Postweaning ${ }^{5}$} & Starter concentrate & $0.3 \% ; 1 \% ; 3 \% \mathrm{DM}$ & 58 to 90 & $+^{\#}$ & $+^{*}$ & & Ślusarczyk et al. (2010) \\
\hline & & $0.15 \% ; 0.3 \% ; 5.0 \%$ (as fed) & 35 to 70 & Ns & Ns & Ns & Serbester et al. (2014) \\
\hline
\end{tabular}

$\mathrm{DM}=$ dry matter

${ }^{1}$ The level of statistical significance in differences between effects on calves fed butyrate supplemented $v$. unsupplemented feeds was declared (at $P$-value): Ns $P>0.1$;

${ }^{\#} P \leqslant 0.1 ;{ }^{*} P \leqslant 0.05 ;{ }^{* *} P \leqslant 0.01 ;(+)$ increase; (-) decrease.

${ }^{2}$ Estimated as a ratio: feed consumption/BW gain $(\mathrm{kg} / \mathrm{kg})$.

3Preweaning: from 3 to 62 days of age.

${ }^{4}$ Estimated during the period from 5 to 12 days of age.

${ }^{5}$ Postweaning: from weaning to 90 days of age.

butyrate supplementation (Shen et al., 2005; Gorka et al., 2009; Guilloteau et al., 2010; Kato et al., 2011; Shen et al., 2012). All of these proteins and peptides are considered hormonal signals that regulate the nutrient absorption, metabolism and growth in mammalian tissues (Shen et al., 2004; Siddle, 2011; Connor et al., 2015). The presented investigations support the multifactorial mechanisms underlying the improvement of performance in calves receiving butyrate supplement. Exogenous butyrate stimulates these mechanisms and this positive effect is transferred into improving the efficiency of rearing when the supplement is given to calves from the 1st day of life. In light of these facts, it is important to answer the question as to whether the amount of supplied butyrate is optimal to enable its use as a stimulator of calf performance. It is commonly accepted that the most valuable liquid feeds for newborn calves are colostrum and whole cow's milk. Butyrate constitutes about $2.1 \%$ of colostrum DM (Garcia et al., 2014) and $\sim 1.2 \%$ of milk DM (Ceballos et al., 2009). Twofold higher concentrations of butyrate in the rumen and near twofold higher weight gains are found in 36-day-old calves receiving whole cow's milk from the $1^{\text {st }}$ week of life in comparison with that estimated in calves fed milk replacer without milk fat (Niwińska and Strzetelski, 2004). The quantity of butyrate in these natural liquid feeds is significantly greater than in experimental milk replacers contained about $0.3 \%$ of DM. The results suggested that the delivered amount of butyrate in experimental milk replacer may be too low to be considerably evident in improving calf performance. To our knowledge, the effects of the greater amounts of exogenous butyrate given to calves in milk replacer soon after birth have not been investigated. Further research on these aspects is needed.

There are conflicting reports regarding the practical effects in terms of improvements in calf performance when butyrate administration as a component of a starter concentrate is provided from the $2^{\text {nd }}$ week of calf life. Within the period from 2 to 5 weeks of life, together with the greater solid feed intake, the ruminal fermentation increases, as is confirmed by the constant increase in butyrate concentration from 0.002 to $0.01 \mathrm{mM} / \mathrm{l}$ in calf rumen (Lesmeister and Heinrichs, 2004). The response to exogenous butyrate administration could be noticeable in the increase in the ruminal concentration of butyrate and subsequent calf performance. However, the presented effects have been both positive (Ślusarczyk et al., 2010) and negative (Wanat et al., 2015). An increase in daily weight gain and starter concentrate DM intake, at a probability of 0.05 , is observed in calves receiving sodium butyrate at $0.3 \%, 1.0 \%$ and $3.0 \%$ of concentrate containing $30 \%$ of corn and $30 \%$ of wheat grains (Ślusarczyk et al., 2010). In contrast, a linear decrease in daily weight gains and starter intake, at a probability of at least 0.02 , are observed along with the increasing inclusion rate of sodium butyrate from $0.3 \%, 0.6 \%$ to $0.9 \%$ in the starter containing a twofold lower amount of corn and a 1.5-fold higher level of barley and wheat grains (Wanat et al., 2015). The discrepancy in calf performance between the presented results could be explained by the differences in the 
rates and extents of ruminal starch fermentation existing among cereal grains included in the experimental concentrates. The starch of corn is digested in the rumen at $55 \%$ to $70 \%$, with a degradation rate from $4.0 \%$ to $6.4 \% / \mathrm{h}$. The starches of barley and wheat are digested at $80 \%$ to $90 \%$, with degradation rates from $14.7 \%$ to $24.5 \% / \mathrm{h}$ in the mature rumen (Huntington, 1997). The rate of starch fermentation in developing calves affects the ruminal $\mathrm{pH}$, which in 35-dayold calves is higher in calves fed a corn diet than in calves receiving barley or wheat diets (Khan et al., 2008). The increase in highly degradable starch content by up to $58 \%$ causes an increase in the ruminal butyrate concentration from 7.2 to $15.8 \mathrm{mM} / \mathrm{l}$, but at the same time induces ruminal $\mathrm{pH}$ depression to below 5.3, accompanied by the cellular necrosis and disruption of tight junctions in the ruminal epithelial tissue (Liu et al., 2013). It is also worth noting that a rumen $\mathrm{pH}<5.5$ predisposes calves to rumen acidosis (Wood et al., 2015; Khan et al., 2016). In response to a doubling in butyrate concentration, a dysfunction of the rumen microbial ecosystem is observed in adult cattle (Li et al., 2012). Presented results clearly indicate that the role of butyrate supplement is related to the risk of perturbation in the ruminal fermentation and the ruminal epithelial tissue organization in calves. The lower risk is noted in calves fed with starter concentrate with a slowly degradable starch and the higher in calves received starter with substantial content of a rapidly degradable starch. At present, only two studies have presented the practical effects of provision of butyrate as a component of starter concentrate before weaning on calf performance, and investigations results reveal contrasting effects. The problems are not sufficiently well recognized; further studies are required to establish the relation between butyrate supplementation and the starter diet composition.

\section{Conclusions}

Recent scientific reports clearly indicate that the enlargement of the ruminal epithelium surface area and the development of ruminal epithelial cells capabilities for oxidation of SCFA in the ketogenesis pathway is stimulated by dietary supplementation with butyrate. Such reports have presented the direct positive effects on the activities of genes, proteins and transcription factors related to the cell proliferation, butyrate uptake, ketone body formation, the maintenance of intracellular $\mathrm{pH}$ and energy homeostasis and also the transportation of butyrate metabolites into the capillary bed. These results indicate that exogenous butyrate is a factor stimulating functional development of ruminal epithelial cells. The transfer of the accelerated development of the ruminal epithelial tissue into improvement of calf performance is inconclusive. This is more pronounced in calves receiving a supplement in the form of sodium butyrate at the level of about $0.3 \%$ of diet DM not later than during the $1^{\text {st }}$ week of life. A positive effect on the daily weight gain, at a probability of at least 0.1 , has been reported. In light of the higher weight gains observed in calves fed whole cow's milk containing $\sim 1.2 \%$ of butyrate in milk $\mathrm{DM}$, the amount of butyrate in experimental milk replacer may be too low to be considerably evident in improving calf performance. The effects of greater amounts of exogenous butyrate given to calves in milk replacer soon after birth have not been investigated and further research on these aspects is needed. Reports regarding improvements in calf performance in terms of sodium butyrate administration as a component of starter concentrate indicate that this effect relates to the risk of depression of $\mathrm{pH}$ the rumen in calves. A high proportion of rapidly fermentable starch decreases ruminal pH below 5.3, accompanied by the cellular necrosis and disruption of tight junctions in the ruminal epithelial tissue. Currently, only two studies have presented practical effects of the provision of butyrate as a component of starter concentrate before weaning on the performance of calves, and investigations reveal the contrasting results. The relationship between the development of ruminal epithelium in calves and the improvement of calf performance is still largely unknown and this is an area for future investigation. The strategies for improving calf performance are not sufficiently well recognized. There is insufficient information to deserve a supplementary recommendation.

\section{Acknowledgments}

This work was a part of the Ruminant Nutrition project established by National Research Institute of Animal Production in Poland. The authors are thankful to anonymous reviewers for their valuable comments that improved earlier versions of this manuscript.

\section{References}

Albrecht E, Kolisek M, Viergutz T, Zitnan R and Schweigel M 2008. Molecular identification, immunolocalization, and functional activity of a vacuolar-type H1-ATPase in bovine rumen epithelium. Journal of Comparative Physiology B 178, 285-295.

Allen MS 2014. Drives and limits to feed intake in ruminants. Animal Production Science 54, 1513-1524.

Araujo G, Terré M, Mereu A, Ipharraguerre IR and Bach A 2015. Effects of supplementing a milk replacer with sodium butyrate or tributyrin on performance and metabolism of Holstein calves. Animal Production Science 56, 1834-1841.

Baldwin RL and Jesse WB 1992. Developmental changes in glucose and butyrate metabolism by isolated sheep rumen epithelial cells. The Journal of Nutrition 122, 1149-1153.

Baldwin RL VI, McLeod KR, Klotz JL and Heitmann RN 2004. Rumen development, intestinal growth and hepatic metabolism in the pre- and postweaning ruminant. Journal of Dairy Science 87 (suppl. E), 55-65.

Bergman EN 1990. Energy contributions of volatile fatty acids from the gastrointestinal tract in various species. Physiological Reviews 70, 567-590.

Cavini S, Iraira S, Siurana A, Foskolos A, Ferret A and Calsamiglia S 2015. Effect of sodium butyrate administered in the concentrate on rumen development and productive performance of lambs in intensive production system during the suckling and the fattening periods. Small Ruminant Research 123, 212-217.

Ceballos LS, Morales ER, de la Torre Adarve G, Castro JD, Martınez LP and Sampelayo MRS 2009. Composition of goat and cow milk produced under similar conditions and analyzed by identical methodology. Journal of Food Composition and Analysis 22, 322-329.

Connor EE, Baldwin RL VI, Li C, Li RW and Chung H 2013. Gene expression in bovine rumen epithelium during weaning identifies molecular regulators 
of rumen development and growth. Functional and Integrative Genomics 13, 33-142.

Connor EE, Baldwin RL VI, Walker MP, Ellis SE, Li C, Kahl S, Chung H and Li RW 2014. Transcriptional regulators transforming growth factor- $\beta 1$ and estrogen-related receptor- $\alpha$ identified as putative mediators of calf rumen epithelial tissue development and function during weaning. Journal of Dairy Science 97, 4193-4207.

Connor EE, Evock-Clover CM, Walker MP, Elsasser TH and Kahl S. 2015. Comparative Gut Physiology Symposium: comparative physiology of glucagonlike peptide-2: implications and applications for production and health of ruminants. Journal of Animal Science 93, 492-502.

Dengler F, Rackwitz R, Benesch F, Pfannkuche H and Gäbel G 2015. Both butyrate incubation and hypoxia upregulate genes involved in the ruminal transport of SCFA and their metabolites. Journal of Animal Physiology and Animal Nutrition 99, 379-390.

Donohoe DR, Collins LB, Wali A, Bigler R, Sun W and Bultman SJ 2012. The Warburg effect dictates the mechanism of butyrate-mediated histone acetylation and cell proliferation. Molecular Cell 48, 612-626.

Etschmann B, Heipertz KS, von der Schulenburg A and Schweigel M 2006. A vH+-ATPase is present in cultured sheep ruminal epithelial cells. American Journal of Physiology. Gastrointestinal and Liver Physiology 291, G1171-G1179.

Gäbel G, Aschenbach JR and Muller F 2002. Transfer of energy substrates across the ruminal epithelium: implications and limitations. Animal Health Research Reviews 3, 15-30.

Gäbel $G$ and Sehested J 1997. SCFA transport in the forestomach of ruminants. Comparative Biochemistry and Physiology 118A, 367-374.

Garcia M, Greco LF, Favoreto MG, Marsola RS, Martins LT, Bisinotto RS, Shin JH, Lock AL, Block E, Thatcher WW, Santos JEP and Staples CR 2014. Effect of supplementing fat to pregnant nonlactating cows on colostral fatty acid profile and passive immunity of the newborn calf. Journal of Dairy Science 97, 392-405.

Górka P, Kowalski ZM, Pietrzak P, Kotunia A, Jagusiak W, Holst JJ, Guilloteau P and Zabielski R 2011a. Effect of method of delivery of sodium butyrate on rumen development in newborn calves. Journal of Dairy Science 94 5578-5588.

Górka P, Kowalski ZM, Pietrzak P, Kotunia A, Jagusiak W and Zabielski R 2011 b. Is rumen development in newborn calves affected by different liquid feeds and small intestine development? Journal of Dairy Science 94, 3002-3013.

Gorka P, Kowalski ZM, Pietrzak P, Kotunia A, Kiljanczyk R, Flaga J, Holst JJ, Guilloteau P and Zabielski R 2009. Effect of sodium butyrate supplementation in milk replacer and starter diet on rumen development in calves. Journal of Physiology and Pharmacology 60, 47-53.

Graham C, Gatherar I, Haslam I, Glanville M and Simmons NL 2007. Expression and localization of monocarboxylate transporters and sodium/proton exchangers in bovine rumen epithelium. American Journal of Physiology. Regulatory, Integrative and Comparative Physiology 292, R977-R1007.

Guilloteau P, Savary G, Jaguelin-Peyrault $Y$, Romé V, Le Normand L and Zabielski $R$ 2010. Dietary sodium butyrate supplementation increases digestibility and pancreatic secretion in young milk-fed calves. Journal of Dairy Science 93, 5842-5850.

Guilloteau P, Zabielski R and Blum JW 2009. Gastrointestinal tract and digestion in the young ruminant: ontogenesis, adaptations, consequences and manipulations. Journal of Physiology and Pharmacology 60 (suppl. 3), 37-46.

Hegardt FG 1999. Mitochondrial 3-hydroxy-3-methylglutaryl- CoA synthase: a control enzyme in ketogenesis. Biochemical Journal 338, 569-582.

Huntington GB 1997. Starch utilization by ruminants: from basics to the bunk. Journal of Animal Science 75, 852-867.

Kato D, Suzuki Y, Haga S, So K, Yamauchi E, Nakano M, Ishizaki H, Choi K Katoh K and Roh SG 2016. Utilization of digital differential display to identify differentially expressed genes related to rumen development. Animal Science Journal 87, 584-590.

Kato S, Sato K, Chida H, Roh SG, Ohwada S, Sato S, Guilloteau P and Katoh K 2011. Effects of Na-butyrate supplementation in milk formula on plasma concentrations of $\mathrm{GH}$ and insulin, and on rumen papilla development in calves. Journal of Endocrinology 211, 241-248.

Khan MA, Bach A, Weary DM and von Keyserlingk MAG 2016. Invited review: transitioning from milk to solid feed in dairy heifers. Journal of Dairy Science 99, 885-902.
Khan MA, Lee HJ, Lee WS, Kim HS, Kim SB, Park SB, Baek KS, Ha JK and Choi YJ 2008. Starch source evaluation in calf starter: II. Ruminal parameters, rumen development, nutrient digestibilities, and nitrogen utilization in Holstein calves. Journal of Dairy Science 91, 1140-1149.

King KL and Cidlowski JA 1998. Cell cycle regulation and apoptosis. Annual Review of Physiology 60, 601-617.

Kuzinski J, Zitnan R, Albrecht E, Viergutz T and Schweigel-Röntgen M 2012. Modulation of $\mathrm{v} \mathrm{H}^{+}$-ATPase is part of the functional adaptation of sheep rumen epithelium to high-energy diet. American Journal of Physiology. Regulatory, Integrative and Comparative Physiology 303, R909-R920.

Laarman AH, Ruiz-Sanchez AL, Sugino T, Guan LL and Oba M 2012. Effects of feeding a calf starter on molecular adaptations in the ruminal epithelium and liver of Holstein dairy calves. Journal of Dairy Science 95, 2585-2594.

Lane MA, Baldwin RL VI and Jesse BW 2002. Developmental changes in ketogenic enzyme gene expression during sheep rumen development. Journal of Animal Science 80, 1538-1544.

Lesmeister KE and Heinrichs AJ 2004. Effects of corn processing on growth characteristics, rumen development, and rumen parameters in neonatal dairy calves. Journal of Dairy Science 87, 3439-3450.

Li RW, Wu S, Baldwin RL 6th, Li W and Li C 2012. Perturbation dynamics of the rumen microbiota in response to exogenous butyrate. Plos One 7, e29392.

Liu JH, Xu TT, Liu YJ, Zhu WY and Mao SY 2013. A high-grain diet causes massive disruption of ruminal epithelial tight junctions in goats. American Journal of Physiology. Regulatory, Integrative and Comparative Physiology 305, R232-R241.

Madshus IH 1988. Regulation of intracellular pH in eukaryotic cells. Biochemical Journal 250, 1-8.

Malhi M, Gui H, Yao L, Aschenbach JR, Gäbel G and Shen Z 2013. Increased papillae growth and enhanced short-chain fatty acid absorption in the rumen of goats are associated with transient increases in cyclin D1 expression after ruminal butyrate infusion. Journal of Dairy Science 96, 7603-7616.

Mentschel J, Leiser R, Mülling C, Pfarrer C and Claus R 2001. Butyric acid stimulates rumen mucosa development in the calf mainly by a reduction of apoptosis. Archives of Animal Nutrition 55, 85-102.

Naeem A, Drackley JK, Stamey J and Loor JJ 2012. Role of metabolic and cellular proliferation genes in ruminal development in response to enhanced plane of nutrition in neonatal Holstein calves. Journal of Dairy Science 95, 1807-1820.

Nazari M, Karkoodi K and Alizadeh A 2012. Performance and physiological responses of milk-fed calves to coated calcium butyrate supplementation. South African Journal of Animal Science 42, 296-303.

Niwińska B and Strzetelski J 2004. Effects of type of liquid feed and feeding frequency on rumen development and rearing performance of calves. Journal of Animal and Feed Sciences 13 (suppl. 1), 167-170.

Rémond D, Ortigues I and Jouany JP 1995. Energy substrates for the rumen epithelium. Proceedings of the Nutrition Society 54, 95-105.

Sakata T and Tamata H 1978. Influence of butyrate on microscopic structure of ruminal mocosa in adult sheep. Japanese Journal of Zootechnical Science 49, 687-696.

Sander EG, Warner RG, Harrison N and Loosli JK 1959. The stimulatory effect of sodium butyrate and sodium propionate on the development of rumen mucosa in the young calf. Journal of Dairy Science 42, 1600-1605.

Schweigel M, Vormann J and Marten $\mathrm{H} 2000$. Mechanisms of $\mathrm{Mg}^{2+}$ transport in cultured ruminal epithelial cells. American Journal of Physiology. Gastrointestinal and Liver Physiology 278, G400-G408.

Serbester U, Çakmakçi C, Göncü S and Görgülü M 2014. Effect of feeding starter containing butyrate salt on pre- and post-weaning performance of early or normally weaned calves. Revue de Médecine Vétérinaire 165, 44-48.

Shen Z, Holger M and Schweigel-Röntgen M 2012. $\mathrm{Na}^{+}$transport across rumen epithelium of hay-fed sheep is acutely stimulated by the peptide IGF-1 in vitro. Experimental Physiology 97, 497-505.

Shen Z, Kuhla S, Zitnan R, Seyfert HM, Schneider F, Hahemeister H, Chudy A, Löhrke B, Blum JW, Hammon HM and Voigt J 2005. Intraruminal infusion of $n$-butyric acid induces an increase of ruminal papillae size independent of IGF-1 system in castrated bulls. Archives of Animal Nutrition 59, 213-225.

Shen Z, Seyfert HM, Löhrke B, Schneider F, Zitnan R, Chudy A, Kuhla S, Hammon HM, Blum JW, Martens H, Hagemeister H and Voigt J 2004. An energy-rich diet causes rumen papillae proliferation associated with more IGF type 1 receptors 
and increased plasma IGF-1 concentrations in young goats. Journal of Nutrition 134, 11-17.

Siddle K 2011. Review: signalling by insulin and IGF receptors: supporting acts and new players. Journal of Molecular Endocrinology 47, R1-R10.

Ślusarczyk K, Strzetelski JA and Furgał-Dierżuk I 2010. The effect of sodium butyrate on calf growth and serum level of $\beta$-hydroxybutyric acid. Journal of Animal and Feed Sciences 19, 348-357.

Storm C, Kristensen NB and Hanigan MD 2012. A model of ruminal volatile fatty acid absorption kinetics and rumen epithelial blood flow in lactating Holstein cows. Journal of Dairy Science 95, 2919-2934.

Súarez BJ, Van Reenen CG, Stockhofe N, Dijkstra J and Gerrits WJJ 2007 Effect of roughage source and roughage to concentrate ratio on animal performance and rumen development in veal calves. Journal of Dairy Science 90, 2390-2403.

Wanat P, Górka P and Kowalski ZM 2015. Short communication: effect of inclusion rate of microencapsulated sodium butyrate in starter mixture for dairy calves. Journal of Dairy Science 98, 2682-2686.

Wood KM, Palmer SI, Steele MA, Metcalf JA and Penner GB 2015. The influence of age and weaning on permeability of the gastrointestinal tract in Holstein bull calves. Journal of Dairy Science 98, 7226-7237.

Yan L, Zhang B and Shen Z 2014. Dietary modulation of the expression of genes involved in short-chain fatty acid absorption in the rumen epithelium is related to short-chain fatty acid concentration and $\mathrm{pH}$ in the rumen of goats. Journal of Dairy Science 97, 5668-5675. 